\title{
The Use of the Elements of Neuroandragogy in the Religious Education of the Elderly
}

The need to enliven the catechesis of the elderly and to take advantage of the richness and experience of this social group resounds significantly in contemporary catechetical reflection. The Directory for Catechesis states that

the elderly are the treasure of memory and often guardians of values of a given community. (...) The Church sees the elderly as God's gift, as the richness of the community, and considers it to be its responsibility to provide them with pastoral care ${ }^{2}$.

Bearing in mind the fact that society, and thus the Church community, is affected by the progressive aging of its members, there is a need to direct appropriate resources and measures in this area of ministry.

As for the catechetical dimension, it will be important, among others, to take proper steps related to appropriate content, tools and structure in order to adjust the catechesis of the elderly. The suggested specific educational offer should stimulate and encourage to verify and deepen one's own religious knowledge, help answer nagging questions, especially existential ones, in an eschatological perspective, and find a place and role for the elderly in the community of believers.

By analyzing the fundamental assumptions of neuroandragogy, this article will present the possibilities of using the selected elements of this pedagogical current in catechesis and the broadly understood religious education of the elderly.

\footnotetext{
${ }^{1}$ Mirosław Gogolik - assoc. prof. Adam Mickiewicz University in Poznań, Faculty of Theology, e-mail: mirgo@amu.edu.pl, ORCID: 0000-0001-5186-769X.

${ }_{2}$ Papieska Rada ds. Krzewienia Nowej Ewangelizacji, Dyrektorium o katechizacji, No. 266, Kielce 2020, (hereinafter: DK) 


\section{The notion of old age and aging in social and theological thought}

The notion of old age and aging can be considered in two ways, namely as an individual entity and as a phenomenon concerning the aggregate of these entities, i.e. a society of a given region, country or part of the world. In an individual aspect, old age is a biological phenomenon which is part of the human life cycle, a stage in a person's life and development following adulthood. This stage conventionally begins after the age of 60 , manifests itself in the weakening of the biological functions of the body, changes in mental fitness and social adaptation, as well as a stronger awareness of the twilight of life and spiritual eschatological space $^{3}$. On the other hand, aging, in the context of an aggregate phenomenon, is understood as a process of progressive deterioration of the vital functions of a social organism, which, along with the increased probability of death, struggles with the difficulties of performing basic tasks in the life of a social group. Three areas of aging can be distinguished:

a) biological, characterized by the atrophy and impairment of the functions of cells and tissues;

b) mental, characterized by the decline and disappearance of mental functions;

c) social, characterized by withdrawal from fulfilling social roles and performing tasks.

Aging, according to the description adopted in psycho-gerontological literature, means a certain process and its character is dynamic, irreversible. On the other hand, old age as a state is static, although it is not homogeneous and can be divided into successive periods ${ }^{4}$.

In addition to biological, psychological and social aspects, old age and aging can also be considered from a theological, i.e. spiritual and religious perspective. The Old Testament contains guidelines and provisions of the Law, referring to exceptional care for widows, orphans and strangers, i.e. weak people, often poor and vulnerable to isolation in society.

You shall not wrong a stranger or oppress him, for you were strangers in the land of Egypt. You shall not afflict any widow or orphan. If you do afflict them, and they cry out to me, I will surely hear their cry; and my wrath will burn, and I will

${ }^{3}$ Cf. P. Ostański, Starość, in: Encyklopedia Katolicka KUL, t. 18, Lublin 2013, c. 854; Cf. Starzenie się, in: Nowa encyklopedia powszechna PWN, t. 6, Warszawa 1996, p. 32; Cf. J. G. Harris, Biblical Perspectives on Aging. God and the Elderly, New York 2008.

${ }^{4}$ Cf. K. Porzych, K. Kędziora-Kornatowska, A. Polak, M. Porzych, Psychologiczne aspekty starzenia się i starości, "Gerontol Pol” 2004, 12(4), pp. 165-168; Cf. A. Skreczko, Starość, in: Slownik matzeństwa i rodziny, red. E. Ozorowski, Warszawa-Lomianki 1999, p. 425; Cf. H. Mieskes, Geragogik-Paedagogik des Alters und des altern Menschen, "Paedagogische Rundschau" 2(1970), pp. 90-101. 
kill you with the sword, and your wives shall become widows and your children fatherless (Ex. 22:20-23).

The above fragment from the Book of Exodus is an attempt to formulate a kind of social welfare law, unprecedented in any other nation at that time, and largely referring to the elderly. The Bible also describes the biological and psychological aspects of old age and aging, as manifested in the body's infirmity (Eccl. 12:1-7) and the fear of waiting for death (Ps 88). In the first centuries of Christianity, in accordance with the teachings of Jesus Christ and the Apostles, the early Church followed the principle of respect for older men and women, understanding for physical and mental weaknesses (1 Tim. 5:1), as well as special care for widows, "Pure, unspoilt religion, in the eyes of God our Father, is this: coming to the help of orphans and widows in their hardships" (Jas. 1:27). An important task of the living community, especially the religious community, is to accompany the elderly during the time of imminent death and prepare them for the transition from this world to eternal life, with the hope of resurrection (Rom. 5:6).

The Church in her teaching of the Second Vatican Council, for instance in the Decree on the Apostolate of the Laity, emphasizes that the apostolate which deserves attention today is not only the one that provides the elderly with the necessary means of life, but above all, creates the possibility of their rightful participation in the results of technological progress 5 . On the other hand, in the Pastoral Constitution on the Church in the Modern World, the Council Fathers draw attention to the need for the care of the Church community, especially children and family members, to maintain appropriate living conditions and dignity of the elderly, resulting from gratitude, genuine respect, trust and filial support of seniors who struggle with the difficulties of everyday life and loneliness in old age ${ }^{6}$. An equally important voice of the Church, emphasizing the value of the senior age and the need for respect for the wisdom and life experience of the elderly, were the words of John Paul II in his 1999 Letter to the Elderly. The Pope shows, among other things, the value of the testimony of the elderly, and especially their irreplaceable teaching role for future generations, which allows to safeguard the collective memory of human achievements and shows the way of hope leading to the eternity of life as the fulfillment of man's vocation ${ }^{7}$. The above outlined social and theological perspective, describing the phenomenon of

${ }^{5}$ Cf. Sobór Watykański II, Dekret o apostolstwie świeckich, No. 11, in: Sobór Watykański II, Konstytucje, dekrety, deklaracje, Poznań-Warszawa 1967.

${ }^{6}$ Cf. Sobór Watykański II, Konstytucja duszpasterska o Kościele w świecie wspótczesnym, No. 48, 66, in: Sobór Watykański II, Konstytucje, dekrety, deklaracje, Poznań-Warszawa 1967.

7 Jan Paweł II, List do osób w podeszłym wieku, http://www.opoka.org.pl/biblioteka/W/WP/ jan_pawel_ii/listy/do_starszych_01101999.html \# [accessed on 07.04.2021]. 
aging and old age, should also be extended to include pedagogical thought and new trends in andragogy.

\section{What is neuroandragogy?}

Answering the above question related to neuroandragogy, it is first worth referring to pedagogical thought and andragogical assumptions. In the basic lexical description, the term andragogy refers to a field of pedagogy which deals with the problems of education, self-education, as well as the upbringing of adolescents and adults. The dynamically developing area of lifelong and distance learning has become the subject researched by educators, psychologists and sociologists to define the goals, content, methods, means and organizational forms of adult education ${ }^{8}$. Other names used to denote andragogy are adult pedagogy, theory of education and upbringing of working youth and adults.

Conducting research, andragogy serves to construct, strengthen and develop modern society, its economy, politics, culture and science by helping to shape man. $\mathrm{He}$ is to be enlightened, creative, socialized, sensitive to beauty, physically fit, devoted to the freedom of a country and constantly improve himself 9 .

Currently, several areas of research can be distinguished, namely general andragogy, dealing with the description of the goals and methods of upbringing adults as well as analyzing the policies and organization of educational and cultural institutions; and specific andragogy, which covers the issues of adult didactics, the theory of upbringing, and the history of adult education ${ }^{10}$.

Until the 1970s, most learning theories had stemmed from psychology and were very general in nature, often assuming that learning ran in the same way for everyone, be it children or adults. The development of pedagogical thought and concentration on researching the area of adult education shed new light on the issue, pointing mainly to specific and typical elements of adult learning. Research conducted in this field allowed to highlight the fundamental differences between children's learning and adult learning, and then to indicate their practical implications in educational situations. The result of the undertaken work was the publication of several significant books proving the existence of fundamental learning

${ }^{8}$ Cf. Andragogika, in: C. Kupisiewicz, M. Kupisiewicz, Stownik pedagogiczny, Warszawa 2009, p. 11.

${ }^{9}$ K. Wojciechowski, Andragogika, in: Encyklopedia pedagogiczna, red. W. Pomykało, Warszawa 1996, p. 25.

${ }^{10}$ Cf. Ibidem, p. 26. 
differences between children and adults, and emphasizing that both educational theory and practice should necessarily take them into account when organizing the learning environment. The most important ones were: Cyril Houle (1972) The Design of Education ${ }^{11}$; Malcolm Knowles (1973) The Adult Learner: A Neglected Species ${ }^{12}$; Roby Kidd (1978) How Adults Learn ${ }^{13}$.

At this point, it is worth focusing on theses developed by Malcolm Knowles, who designed an adult learning model called andragogy. This model is based on a set of assumptions concerning adult learning. In his opinion, adults:

- must know why they need to learn something before they start the process;

- must transition from dependence in learning to self-education;

- accumulate numerous and varied experiences, different from children's experiences;

- demonstrate relationships between readiness to learn and tasks inscribed in their social roles and life stages;

- are more willing to engage in learning focused on specific problems rather than general learning about a given subject;

- are driven by intrinsic rather than extrinsic motivation ${ }^{14}$.

Having outlined the fundamentals of andragogy, one can proceed to answering the question about what neuroandragogy is distinguished by and what contribution it makes to the development of adult education. In the educational space, neuroandragogy is described as "an interdisciplinary field combining elements of neuropsychology, neurophysiology, and neuroanatomy with the existing knowledge about adult education" ${ }^{15}$. The definition of neuroandragogy provided above clearly indicates a wide research scope, covering cooperation and the use of knowledge from many fields. In recent years, research and achievements in the field of medicine, especially neurology and neurobiology, have been attracting a lot of interest. They provide valuable information related to the functioning and development of the human brain.

Using basic knowledge about the structure and functions of the human brain, one can look at human education as a process that dynamically uses the functions of the brain. The process of connecting many nerve cells by means of axons and dendrites makes it possible to transmit and evaluate information. It also makes it possible to collect useful information in appropriate places in the brain and

${ }^{11}$ C. Houle, The Design of Education, Michigan 1972.

${ }^{12}$ M. Knowles, The Adult Learner: A Neglected Species, Houston 1973.

13 J. R. Kidd, How Adults Learn, Englewood Cliffs 1978.

${ }^{14}$ Cf. Edukacja dorostych, red. M. S. Knowles, E. F. Holton, R. A. Swanson, Warszawa 2009, pp. 71-72.

${ }_{15}$ Neuroandragogika w edukacji dorostych zagrożonych wykluczeniem. Materiały dla nauczycieli $i$ edukatorów osób dorostych, http://www.neuroandragogy.eu/wp-content/uploads/2018/10/ neuro_io2_pl_lekki.pdf [accessed on 08.04.2021], p. 4. 
reject the one which is negative. In such a dynamic system of brain development, an important role is played by the time of education and learning-teaching factors which reach nerve cells. Therefore, over the past decades, a new field has emerged in the current of pedagogical thought, namely neuropedagogy, also called by some members of the educational world - the 21 st century pedagogy.

It must be based on the knowledge (with understanding) of the structure and functions of the brain, e.g. the knowledge of sensory preferences, differences in the functioning of cerebral hemispheres, profiles of the dominance of a cerebral hemisphere in combination with the dominance of an eye, ear, hand, leg and its consequences for the learning style and, for example, reaction to stress; also of the impact of stress on various types of memory, the effectiveness of learning, and finally of the creation of appropriate psychoemotional states that optimize the course of learning ${ }^{16}$.

The above assumptions are now used in a significant way in didactic activities, understood as neurodidactics. Marzena Żylińska emphasizes that neurodidactics is not an entirely new concept.

It was created around the mid-1980s, and its founder is German mathematics educator Gerhard Preiß. As for English, the following terms are used: "brainfriendly learning" and "braincompatible learning". In Poland, the term "neurodidactics" is becoming increasingly popular and functions both in professional and popular science literature ${ }^{17}$.

The above concept of learning-teaching is also referred to as brainfriendly learning, which implies:

- using the strengths of the brain,

- being based on intrinsic motivation and positive emotions,

- appreciating and emphasizing in the process of learning the role of understanding and individual provision of meanings.

Therefore, it is necessary:

- to develop children's cognitive curiosity, stimulate them to solve problems, perform tasks, discover relationships and seek explanations,

- to create an atmosphere of safety and concentration, individual treatment,

- to appreciate pupils' individual talents and gifts, interests and possibilities,

${ }^{16}$ M. Taraszkiewicz, Neuropedagogika - edukacja 21 wieku, https://www.edunews.pl/ badania-i-debaty/opinie/244-neuropedagogika-edukacja-21-wieku [accessed on 08.04.2021].

${ }^{17}$ M. Żylińska, Neurodydaktyka, czyli nauczanie przyjazne mózgowi, www.ore.edu.pl [accessed on 08.04.2021], p. 1 . 
- to take care of an appropriate channel of knowledge transfer, communicativeness through combining cognitive knowledge with emotions,

- to use active and project-based methods and to take into account the process of acquiring knowledge, the need for a constructivist approach, and the proper inherent understanding of errors ${ }^{18}$.

Neuroandragogy, therefore, drawing on the current knowledge of the functioning of the brain of adults and the elderly, introduces appropriate didactic tools, as well as diagnoses and describes the following issues:

- deepening the knowledge of issues related to the maturing and aging of the brain and the influence of these processes on humans' intellectual performance;

- developing orientation in the course of the process of receiving stimuli from the environment, which allows to assess the potential effectiveness or ineffectiveness of the applied didactic impact measures;

- gathering the knowledge of the course of information processing in the brain, which facilitates the selection of methods, techniques and didactic tools to individual cognitive conditions of adult learners;

- mastering the structure of storing data in memory, which enables a proper selection of the type of a student's activity in relation to the type of memory with which the activity correlates;

- using the knowledge of the brain's reward system operation model, thanks to which it can be properly moderated, controlling motivation to study and work;

- studying the impact of stress on the learning process, which in turn facilitates building a positive educational atmosphere, conducive to learning and developing experiences ${ }^{19}$.

Research concerning neuroandragogy, based on modern medical knowledge related to changes taking place in the adult brain, indicates a need to pay attention to the following elements of the evolution of brain functions:

- "the speed of cerebral operations decreases - a mature person needs more time to perform a specific mental operation than a young person;

- functions such as inhibition, concentration, reflex reactions (located in the frontal lobes, subject to degeneration in the first place) are weakened;

- working memory capacity decreases - a person is able to process simultaneously a smaller amount of information provided by the senses;

- mental flexibility decreases (the ability to quickly switch between one intellectual operation to another);

${ }^{18}$ Cf. M. Żylińska, Neurodydaktyka. Nauczanie i uczenie się przyjazne mózgowi, Toruń 2013, pp. 286-290.

${ }^{19}$ Cf. Neuroandragogika w edukacji dorostych..., op. cit., p. 4. 
- selective attention is disturbed (the ability to capture and concentrate on significant context-related events);

- divided attention is weakened (the ability to draw attention to different actions taking place at the same time);

- semantic memory (responsible for rules, definitions, general principles) and episodic memory (recording events in time) are weakened" 20 .

Thanks to the above interdisciplinary indications, andragogy and neuroandragogy developed important tools in educational work with adults. They singled out, among others, the area of adult learning from everyday life: practical, in the workplace and institutionalized. A special element in the learning process of adults and the elderly will be the possibility and necessity to use the acquired knowledge and experience, self-education skills, reflective and transformative learning, as well as the role of motivation and stress. The above-mentioned elements and assumptions of neuroandragogy can also be used in the religious education of the elderly, which will be analyzed further on in the study.

\section{Basic aspects of the catechesis of the elderly}

Over the past decades, the Church has carefully analyzed and reflected on the catechesis of adults, which is discussed in this study, with particular emphasis on the elderly. In this way, on the basis of the analysis of the current catechetical documents of the Church, one can specify three important aspects of the catechesis of the elderly, covering the following areas:

a) catechetical ministry for the elderly, taking into account relevant content, close to their life experience;

b) supporting seniors as teachers and witnesses to faith in relation to the younger generation;

c) help in determining the place and role of the elderly in and for the benefit of the Church community.

Catechesis, as an educational and evangelizing process, requires adapting its content to the age of recipients and their perception, which results from existential, biological, spiritual and pastoral factors. In the General Catechetical Directory of 1971, the Congregation for the Clergy, drawing attention to the valuable contribution of the elderly to social life through their activity and life experience, states that it is a duty resulting from justice to prepare the elderly for death by catechesis, to instill supernatural hope leading to eternal life ${ }^{21}$.

${ }^{20}$ Ibidem, p. 6 .

${ }^{21}$ Cf. Kongregacja ds. Duchowieństwa, Ogólna Instrukcja Katechetyczna, No. 95, in: Katecheza po Soborze Watykańskim II w świetle dokumentów Kościoła, red. W. Kubik, t. 1, Warszawa 
The above thought and the outlined direction of catechetical activities among the elderly are developed by the Congregation for the Clergy in the General Catechetical Directory, as well as the Directory for Catechesis, issued by the Pontifical Council for Promoting the New Evangelization. In both documents, three groups of addressees of the catechesis of the elderly are clearly emphasized, taking into account the aspect of their faith, that is, different religious experience brought by life. Therefore, the faithful characterized by the following features are distinguished:

- well-grounded and rich faith,

- more or less obscured faith and poor Christian practice,

- experiencing old age with deep wounds in the body and soul (DK 267) 22 . A particularly important aspect, emphasized in the context of individual groups of addressees, will be the adaptation of the content of catechesis, taking into account the above-mentioned question of living and experiencing faith.

Therefore:

- the catechesis of thanksgiving and trustful waiting will be directed at seniors who live their faith in a firmly-established way,

- the catechesis of new light and religious experience should be directed at people with more or less obscured faith,

- on the other hand, catechesis filled with prayer, forgiveness and inner peace should be prepared for the elderly who bear deep wounds in their soul and body (DK 267).

In addition to catechesis for the elderly, special attention is paid in the teaching of the Church to the catechetical role played by seniors in the family and society. In the above-mentioned General Catechetical Directory, one can read that seniors are witnesses to the living presence of God, life immortality and future resurrection. Such eschatological testimony becomes a form of catechesis for the younger generation, an example of patience, kindness, spiritual poverty and trust in God (OIK 95). The aspect of catechesis, which takes place thanks to the testimony of faith of seniors in the Church community and in their own families, is, according to the General Directory for Catechesis, a special gift and role for teachers of faith who, through their presence and love, can confirm the validity of the word of God in the young generation. Thus, a valuable element that the elderly contribute to catechesis is the attitude of wisdom and dialogue, which, by influencing the community and intergenerational relations, can contribute to the growth of faith. Seniors in the family - according to the Directory - become educators of

1985, (hereinafter: OIK); Cf. E. Alberich, A. Binz, Forme e modelli di catechesi con gli adulti, Torino 1995; Cf. L. Soravito, La catechesi degli adulti. Orientamenti e proposte, Torino 1998.

${ }^{22}$ Cf. Kongregacja ds. Duchowieństwa, Dyrektorium ogólne o Katechizacji, No. 186-187, Poznań 1998, (hereinafter: DOK). 
the young generation, their children and grandchildren and those who accompany them in life. This helps to properly develop dialogue and intergenerational relations (DOK 188). The catechetical and evangelizing aspect of the influence of the elderly in the family and society was also highlighted by John Paul II in his Letter to the Elderly, stating that

the Christian community can receive much from the serene presence of older people. I think first of all in terms of evangelization: its effectiveness does not depend principally on technical expertise. In how many families are grandchildren taught the rudiments of the faith by their grandparents! There are many other areas where the elderly can make a beneficial contribution. The Spirit acts as and where he wills, and quite frequently he employs human means which seem of little account in the eyes of the world. How many people find understanding and comfort from elderly people who may be lonely or ill and yet are able to instil courage by their loving advice, their silent prayers, or their witness of suffering borne with patient acceptance! At the very time when their physical energies and their level of activity are decreasing, these brothers and sisters of ours become all the more precious in the mysterious plan of Providence ${ }^{23}$.

Moreover, the latest catechetical document of the Pontifical Council for Promoting the New Evangelization emphasizes the significant role of grandparents in the process of religious upbringing of the young generation, especially in the face of the current family crisis.

Many people owe their initiation into the Christian faith to their grandparents. The contribution of grandparents to catechization therefore appears to be important both because of a greater amount of time that they can devote, and a special ability to encourage grandchildren through their emotional commitment. On multiple occasions, the wisdom of grandparents turns out to be decisive for the development of faith (DK 126).

In its further part, the document calls seniors catechists of the community who, by sharing the wealth of their wisdom and faith, can pass on to young people the meaning of life, the value of tradition, certain religious and cultural practices, give dignity to the memory and sacrifices of past generations, and looking into the future with hope, they teach to overcome immediate difficulties (DK 268).

In addition to the valuable role of the elderly in family catechesis, attention should also be paid to other areas of the Church's life, where seniors, by bringing their experience, wisdom and hope, can carry out the fundamental task of

${ }^{23}$ Jan Paweł II, List do osób w podeszłym wieku, op. cit., No. 13. 
evangelization, and in this way find their place and role in the community of faith. The Catechetical Directory of the Catholic Church in Poland emphasizes the special involvement of seniors in Catholic movements, associations and organizations, as well as in various types of specialist pastoral structures and parish catechesis, primarily aimed at preparation for Christian initiation. According to the above document, the place of catechetical activity of the elderly may also be participation in improving catechesis for animators and those responsible for the life of communities, catechesis related to various experiences of personal life or the life of the Church and local community, as well as spending free time, e.g. pilgrimages ${ }^{24}$. Similarly, this third aspect of the catechesis of the elderly is captured by the Directory for Catechesis, emphasizing the valuable role of seniors in the community of believers who, through the accumulated wisdom of life and the testimony of their own faith, are called to the apostolate of prayer, especially intercession, and to taking care of the needy (DK 268).

In this way, a kind of a triple model of the catechesis of the elderly is realized, in which seniors themselves are first catechized and then become catechists of the community and others, extending their involvement in the Church by sharing their talents, life experience and knowledge. However, in order to actively and fruitfully fulfill this triple task, one also needs to provide seniors with adequate, both intellectual and practical support and preparation.

\section{Religious education of the elderly with the use of the elements of neuroandragogy}

The assumptions of neuroandragogy developed in recent years can facilitate the planning of adult education, also in the field of religious education, taking into account, primarily in the process of teaching adults, information about the functioning of the brain and changes that occur in it at various stages of human life. This knowledge is especially useful for those who are to undertake the task of educating and collaborating with adults and the elderly. In the area of religious activities, one should first and foremost mention pastors, as well as catechists and lay animators, or leaders of religious groups and communities. The most important elements worth paying attention to from the perspective of neuroandragogy will be the acquaintance with issues such as:

- "the process of receiving and processing stimuli from the environment,

- the functioning of various types of memory,

${ }^{24}$ Cf. Konferencja Episkopatu Polski, Dyrektorium Katechetyczne Kościoła Katolickiego $w$ Polsce, No. 102-104, Kraków 2001, (hereinafter: PDK). 
- the role and importance of experience and prior knowledge in the process of remembering and constructing knowledge,

- the differentiation of the operation of cerebral hemispheres,

- the impact of stress and human affective functions on cognitive processes,

- individual differences between learners in terms of sensory preferences, learning styles,

- the conditioning of cognitive functions resulting from maturing and aging processes" 25 .

The constructive elements of adult education mentioned above, resulting from the need to be acquainted with the psychophysical conditions of adults and the elderly, can successfully find their practical application in catechesis conducted in these age groups and in other initiatives and pastoral activities of the Church. In light of the assumptions of andragogy and neuroandragogy, the role of pastors and people responsible for the catechesis and education of the elderly in the Church will, therefore, be:

- to explain to adults why we teach them specific material;

- to support adults in their ability to learn independently, to be self-educated;

- to use their life experience in educational situations whenever possible;

- to make them aware of what activities and social roles they can engage in through their educational effort;

- to learn about and respect the motivational stimuli of elderly learners, even if they are varied.

Bearing in mind different faith-related experiences of the elderly, which the Directory for Catechesis splits into:

- rich and well-established,

- obscured and poor practice,

- having deep wounds in the body and soul, it is necessary, first of all, to awaken in the recipients of catechesis a proper intrinsic motivation, thanks to which persons undertaking an educational effort related to religion will know why they engage in learning and acquiring new information. The aforementioned specific character of experienced faith suggests in planning the catechesis of the elderly taking into account the fact that learning in this age group must be related to the main problems and tasks that a person faces in everyday life, and therefore issues beyond the context and connection with interests and needs of adults should be avoided.

An important feature of the education of the elderly is drawing from the richness of one's own life experience, which in the case of religious education will show the existing familiarity with religious practice and the experience of faith

${ }^{25} O$ neuroandragogice, http://www.neuroandragogy.eu/index.php/pl/o-neuroandragogice/ [accessed on 09.04.2021]. 
experienced every day. The unique structure of experiences gathered by people and their reflection and contemplation about them undoubtedly constitute a wealth for educational and catechetical work in the discussed age group. The life of every adult is a process of continuous accumulation of a unique set of experiences embedded in specific contexts. Therefore, it will be important to pay attention to the fact that reflection results from a person encountering a problematic situation experienced in everyday life, which in the religious space will encompass very delicate and intimate spheres of life and memory. Thus, when organizing formal education, one must remember about sensitivity in relating to authentic experiences and situations which have happened in the lives of particular individuals. It is also worth bearing in mind that religious experiences and old age may become a cause, a source of motivation to engage in religious education, openness to the community of the Church and undertaking specific apostolic activities, e.g. service to the needy. In some situations, the accumulated experience may, unfortunately, also be an obstacle in undertaking activity in the area of faith. Therefore, it is important to properly manage the process of motivation and reflection.

Critical reflection on one's own experiences, including the analysis of one's own experience of faith, especially in an eschatological perspective, which often accompanies the elderly, may result in taking specific actions aimed at transformation. In the andragogical model, in such situations there is an openness to the transformative potential of learning, characterized by the fact that change or personal or social transformations are usually in the centre. Critical reflection undertaken in a specific situation in life provides stimuli to learn or undertake activity in the context of faith practice, and at the same time allows to reassess what is already known and lead to a feeling of deeper internal cohesion. Transformation taking place thanks to the undertaken educational activity is an important factor in experiencing faith outside, which - as shown in the above material - in the case of the elderly is closely related to the role of a community catechist, teacher and witness to faith in relation to the young generation.

In awakening motivation to undertake activity in the dimension of religious education and a senior's involvement in the life of the community of believers, an important role is also played by the experience and ability of self-education, which in andragogy is also called the concept of self-directed learning. Undoubtedly, the space of religious activity, especially undertaken as part of specific roles performed either in a parish community or lay apostolic group causes particular individuals to be often engaged independently in various forms of learning and training in order to supplement and extend their knowledge. Therefore, in the aspect of religious self-education from the perspective of neuroandragogy, it will be primarily important to note that there are always very specific motives behind engaging in education at a given age. Therefore, adults and seniors are able to engage in autonomous, self-directed learning, even if their earlier educational activity and 
interests were not directed towards religious knowledge. From the organizational side of the catechesis of the elderly, one should remember to respect autonomy and be aware of the limitations of self-education in certain situations and in specific kinds of information, especially of theological nature. Thus, pastors play a helpful role in managing the process of religious self-education of seniors, and spiritual guides and confessors help in relation to the development of the spiritual sphere.

Undoubtedly, one of the basic limitations in the work of catechesis at any stage of life may be the lack of mastery of the art of learning, which in the case of seniors also results from the above-mentioned factors related to the aging of the body and changes in brain functions. When organizing a catechetical learning environment for the elderly, it is worth paying attention to the fact that pastors and responsible persons should focus not only on teaching and conveying specific content or skills, but also create an appropriate space for discussion and reflection on one's own experience, limitations, and deficiencies related to the ability to remember and acquire new content, and a loss of concentration and stress, which can often paralyze education at this age. It is necessary to introduce concentration training and memory exercises, which will positively affect the stimulation of specific functions of the brain. It will also be important to use practical knowledge in catechesis and religious activity undertaken by seniors about how they learned the best, most willingly and most effectively earlier, and to help them discover what is the most effective now, and to increase control over their own learning and its effectiveness.

As can be concluded from the above analysis of the possibilities of using the assumptions of neuroandragogy in the religious education of the elderly, a significant role in the proper management of this process is played by people responsible for planning catechesis at the discussed stage and people directly involved in the process of catechesis and animating the activity of seniors in the Church community, i.e. primarily pastors, lay animators and catechists. That is why the postulate which should be articulated relates to the formation and training of persons responsible who conduct catechesis, so that, as part of the integral preparation for catechetical and pastoral service, there would be no lack of in-depth education in the field of the humanities. This postulate resounds in the latest Directory for Catechesis. It emphasizes the need for interdisciplinary preparation of catechists, which will be used to discern and evaluate various psychological, sociological and pedagogical theories, allows to appreciate their value and recognize limitations, and then accept them in the perspective of faith and on the basis of Christian anthropology (DK 147). According to the above-mentioned Directory, catechists, and thus also pastors, are to become

a companion and educator of those who have been entrusted to them by the Church. A catechist is an expert in the art of accompanying, has educational skills, 
can listen to and enter the dynamics of human maturity, patiently and gradually becomes a travel companion, subjecting to the activity of the Spirit and in the process of formation, helping brothers to mature in the Christian life and follow in it towards God. A catechist, being an expert in human nature, knows human joys and hopes, sorrows and concerns, and can relate them to the Gospel of Jesus (DK 113).

Formation for accompanying, in order to be effective, requires first and foremost the experience of accompanying which catechists receive from the Church. In this way, maturing in faith and service, catechists open to the needs of others, sensitive to difficult situations requiring compassion, and also prepared to face difficult existential questions, can become witnesses to the novelty of their ministry, which

consists in closeness, unconditional acceptance and selflessness with which they are ready to walk alongside others, listen to them and explain the Scriptures to them, without charting a route for themselves, without counting on seeing the fruits and keeping them to themselves (DK 135).

Summing up, taking into account the specific character of educational work with adults and the elderly, developed as part of research on andragogy and neuroandragogy, can be a helpful guide in planning catechetical work and broadly understood pastoral work in parish communities. Bearing in mind the fact that the elderly have their own motivation to learn and strictly rely on the already possessed knowledge and experience, as well as adjusting learning to their own goals, which are closely related to currently undertaken activities and roles, it is necessary in catechetical and pastoral planning to undertake a dialogue and diagnose their needs and interests, as well as defining the type of religious experience and activity. Therefore, in managing the catechetical process of the elderly, their own initiative and willingness to educate themselves, striving for autonomy in learning, will be important, and the role of a teacher will be to ensure a safe and favourable catechetical and community environment.

The attitude of accompanying by a catechist and pastor on the path of catechesis and pastoral care among seniors may become a contribution to determining their individual role in the community of the Church and life activity. It will also allow them to be engaged in specific apostolic practices and works, and in this way to acquire new competences.

Reflection and contemplation, which are the basic features of the elderly, are also tangible elements enriching their interpersonal relations and educational impact on the young generation. It is thanks to relying on their own religious and life experiences that seniors become authentic witnesses to faith and catechists 
of the community, especially towards children and youth. With view of the questions and doubts generated by problematic situations faced especially by young people, the authentic attitude and life wisdom of the elderly may become the foundation of the effectiveness of the educational and catechetical process and a source of seeking solutions and answers.

When planning the catechesis of the elderly, one should also take into account the fact that this activity has its time limitations, is often incidental and informal, resulting from a momentary need and situation, and a significant part of learning activities undertaken by seniors cannot be planned and foreseen as a longer process. At the same time, the transformational potential which affords the possibility of reorganizing one's own religious experiences, enriching and deepening the experienced faith, especially in an eschatological perspective, which this kind of pastoral and catechetical ministry can offer among older believers, is a challenge for the contemporary Church community.

\section{Wykorzystanie elementów neuroandragogiki w edukacji religijnej osób starszych}

\section{Streszczenie}

We współczesnej refleksji katechetycznej w sposób znaczący wybrzmiewa potrzeba ożywienia katechezy osób starszych, jak i skorzystania z bogactwa i doświadczenia tejże grupy społecznej. Wynika to przede wszystkim z faktu, iż społeczeństwo, a tym samym wspólnotę Kościoła dotyka problem postępującego starzenia się jej członków. W wymiarze katechetycznym istotnym staje się między innymi podjęcie odpowiednich kroków w celu dostosowania katechezy osób starszych pod względem odpowiednich treści, narzędzi oraz struktury. Proponowana swoista oferta edukacyjna powinna pobudzić oraz zachęcić do weryfikacji i pogłębienia własnej wiedzy religijnej, pomóc odpowiedzieć na nurtujące pytania, zwłaszcza natury egzystencjalnej w perspektywie eschatologicznej, a także odnaleźć miejsce i rolę osób starszych we wspólnocie wierzących. W niniejszym opracowaniu, analizie poddano najpierw pojęcie starości i starzenia się w ujęciu społecznym i teologicznym, następnie przedstawiono podstawowe założenia neuroandragogiki oraz najistotniejsze aspekty katechezy osób starszych. W kolejnej części zaprezentowane zostały implikacje praktyczne dla wykorzystania wybranych elementów andragogiki i neuroandragogiki w katechezie oraz szeroko pojętej aktywności i edukacji religijnej osób starszych.

\section{Slowa kluczowe}

edukacja religijna osób starszych, katecheza osób starszych, andragogika, neuroandragogika 


\section{Summary}

The need to enliven the catechesis of the elderly and to take advantage of the richness and experience of this social group resounds significantly in contemporary catechetical reflection. This is mainly due to the fact that society, and thus the community of the Church, is affected by the problem of the progressive aging of its members. In the catechetical dimension, it becomes important, among other things, to take appropriate steps to adapt the catechesis of the elderly in terms of appropriate content, tools and structure. The suggested specific educational offer should stimulate and encourage to verify and deepen one's own religious knowledge, help answer nagging questions, especially existential ones in an eschatological perspective, and find a place and role of the elderly in the community of believers. In this study, the notion of old age and aging in the social and theological aspect was first analyzed, then the basic assumptions of neuroandragogy and the most important aspects of catechesis of the elderly were presented. The next part featured practical implications for the use of selected elements of andragogy and neuroandragogy in catechesis and the broadly understood activity and religious education of the elderly.

\section{Keywords}

religious education of the elderly, catechesis of the elderly, andragogy, neuroandragogy

\section{Bibliography}

Alberich E., Binz A., Forme e modelli di catechesi con gli adulti, Torino 1995.

Andragogika, in: C. Kupisiewicz, M. Kupisiewicz, Słownik pedagogiczny, Warszawa 2009, p. 11.

Edukacja dorostych, red. M. S. Knowles, E. F. Holton, R. A. Swanson, Warszawa 2009.

Harris J. G., Biblical Perspectives on Aging. God and the Elderly, New York 2008.

Houle C., The Design of Education, Michigan 1972.

Jan Paweł II, List do osób w podeszłym wieku, http://www.opoka.org.pl/biblioteka/W/ WP/jan_pawel_ii/listy/do_starszych_01101999.html\# [accessed on 07.04.2021].

Katecheza po Soborze Watykańskim II w świetle dokumentów Kościoła, red. W. Kubik, t. 1, Warszawa 1985.

Kidd J. R., How Adults Learn, Englewood Cliffs 1978.

Knowles M., The Adult Learner: A Neglected Species, Houston 1973.

Konferencja Episkopatu Polski, Dyrektorium Katechetyczne Kościoła Katolickiego w Polsce, Kraków 2001.

Kongregacja ds. Duchowieństwa, Dyrektorium ogólne o Katechizacji, Poznań 1998.

Kongregacja ds. Duchowieństwa, Ogólna Instrukcja Katechetyczna, in: Katecheza po

Soborze Watykańskim II w świetle dokumentów Kościoła, red. W. Kubik, t. 1, Warszawa 1985.

Mieskes H., Geragogik-Paedagogik des Alters und des altern Menschen, "Paedagogische Rundschau” 2(1970), pp. 90-101. 
Neuroandragogika wedukacji dorostych zagrożonych wykluczeniem. Materiaty dla nauczycieli i edukatorów osób dorostych, http://www.neuroandragogy.eu/wp-content/ uploads/2018/10/neuro_io2_pl_lekki.pdf [accessed on 08.04.2021].

O neuroandragogice, http://www.neuroandragogy.eu/index.php/pl/o-neuroandragogice/ [accessed on 09.04.2021].

Ostański P., Starość, in: Encyklopedia Katolicka KUL, t. 18, Lublin 2013, c. 854-860.

Papieska Rada ds. Krzewienia Nowej Ewangelizacji, Dyrektorium o katechizacji, Kielce 2020.

Pismo Święte Starego i Nowego Testamentu w przekładzie z języków oryginalnych, Poznań-Warszawa ${ }^{3} 1990$.

Porzych K., Kędziora-Kornatowska K., Polak A., Porzych M., Psychologiczne aspekty starzenia się i starości, "Gerontol Pol” 2004, 12(4), pp. 165-168.

Skreczko A., Starość, in: Stownik malżeństwa i rodziny, red. E. Ozorowski, WarszawaŁomianki 1999, pp. 425-429.

Sobór Watykański II, Dekret o apostolstwie świeckich, in: Sobór Watykański II, Konstytucje, dekrety, deklaracje, Poznań-Warszawa 1967.

Sobór Watykański II, Konstytucja duszpasterska o Kościele w świecie współczesnym, in: Sobór Watykański II, Konstytucje, dekrety, deklaracje, Poznań-Warszawa 1967.

Soravito L., La catechesi degli adulti. Orientamenti e proposte, Torino 1998.

Starzenie się, in: Nowa encyklopedia powszechna PWN, t. 6, Warszawa 1996, p. 32.

Taraszkiewicz M., Neuropedagogika - edukacja 21 wieku, https://www.edunews.pl/ badania-i-debaty/opinie/244-neuropedagogika-edukacja-21-wieku [accessed on 08.04.2021].

Wojciechowski K., Andragogika, in: Encyklopedia pedagogiczna, red. W. Pomykało, Warszawa 1996, pp. 25-27.

Żylińska M., Neurodydaktyka, czyli nauczanie przyjazne mózgowi, www.ore.edu.pl [accessed on 08.04.2021].

Żylińska M., Neurodydaktyka. Nauczanie i uczenie się przyjazne mózgowi, Toruń 2013. 